\title{
Safety Culture in Combating Occupational Safety and Health Problems in the Malaysian Manufacturing Sectors
}

\author{
Noor Aina Amirah ${ }^{1}$, Wan Izatul Asma ${ }^{1,2}$, Mohd Shaladdin Muda ${ }^{1} \&$ Wan Abd Aziz Wan Mohd Amin ${ }^{3}$ \\ ${ }^{1}$ Faculty of Management and Economics, Universiti Malaysia Terengganu, Malaysia \\ ${ }^{2}$ Institute of Oceanography and Environment, Universiti Malaysia Terengganu, Malaysia \\ ${ }^{3}$ Faculty of Social Development, Universiti Malaysia Terengganu, Malaysia \\ Correspondence: Wan Izatul Asma, Institute of Oceanography and Environment, Universiti Malaysia Terengganu, \\ Terengganu, Malaysia. Tel: 60-9-668-3620. E-mail: wia@umt.edu.my
}

Received: January 1, 2013 Accepted: January 28, 2013 Online Published: February 28, 2013

doi:10.5539/ass.v9n3p182 URL: http://dx.doi.org/10.5539/ass.v9n3p182

\begin{abstract}
Rapid economic growth via industrialization has given not only a significant impact in terms of income distributions and quality of life, but it also resulted in increasing number of accidents at workplace. In reducing risk at the workplace, Occupational Safety and Health (OSH) is an important aspect. It is a standard which are set in legislation with the aim to eliminate and reduce hazards at workplace. Besides OSH, the term of 'safety culture' is also an important aspect in reducing risk and accident at workplace. This paper highlights the problems in the Malaysian manufacturing industries namely the high accident rate in manufacturing industries which may be due to lack of safety culture and non-compliance of the Malaysian Occupational Safety and Health Act's (OSHA's) requirements which may inadvertently led to lack of safety culture. The existence of these problems shows that workers' and employers' behaviour and compliance to OSHA will lead to positive safety culture which in turn will lead to reduction of accidents rate in the manufacturing industries in Malaysia.
\end{abstract}

Keywords: occupational safety and health, safety culture, safety compliance, malaysian manufacturing industries

\section{Introduction}

Rapid economic growth via industrialization has given not only significant impact in terms of income distributions and quality of life, but it has also resulted in increasing number of accidents at workplace. According to the International Labor Organization (ILO), it is estimated that every year about 2 million workers are killed due to work-related accidents and diseases, 270 million occupational accidents and 160 million work-related diseases are occurring (Soehod \& Laxman 2007). Occupational safety and health (OSH), which is the discipline concerned with preserving and protecting human and facility resources in the workplace, is an important aspect in reducing risk at workplace. OSH is a basically standard which are set in legislation with the aim to eliminate and reduce hazards at workplace. The focus of OSH is to have a healthy and productive workforce for the good of the people and the nation (Abdul Rahman, 2006).

According to Rantanen, Lehtinen \& Savolainen (2004), there are different priorities regarding safety and health between industrialized and developing countries. Priorities in industrially countries are stress, aged workers, workers right to know, chemicals, ergonomics, occupational safety and health management systems and health services. On the other hand, priorities in safety and health in industrially developing countries are agriculture, hazardous occupations like construction and mining, major hazard control, small enterprises, informal sector, occupational diseases reporting and safety, health and child labor. Thus, a good safety management system with the implementation of safety and health legislation will help the employers in promoting safety and health at workplace. Therefore, most Asian countries awareness on the importance of having comprehensive safety and health laws in all types of jobs has started to gain momentum. According to Soehod \& Laxman (2007), Malaysia is the first Asian country to have enacted safety and health legislation covering all occupations. The Occupational Safety and Health Act 1994 (OSHA) covers occupational safety and health in both private and public sectors. The main goal of this Act is to ensure that the employers provide safe working condition to the employees. It promotes for workplace free from any hazards such as exposure to toxic chemicals, excessive 
noise levels, mechanical dangers, heat or cold stress or unsanitary conditions.

Apart from OSH, the terms 'safety culture' is also an important aspect in reducing risks and accidents at workplace. The term 'safety culture' arose due to the Chernobyl major accidents in 1986 (Ostrom, Wilhemsen \& Kaplan, 1993). This term was introduced by the International Atomic Energy Agency (IAEA), (Gad \& Collins, 2002). According to Guldenmund (2000), 'safety culture' is defined as those aspects of the organizational culture which will impact on attitudes and behaviour related to increasing or decreasing risk.

\subsection{Occupational Safety and Health Law in the Malaysian Manufacturing Sectors}

In Malaysia, the role of occupational safety and health has existed since 130 years ago. According to the Department of Occupational Safety and Health (DOSH, 2010), the development of safety and health at workplace can be categorized into five eras. It started with the first era, named Steam Boiler Safety Era, which took place prior to 1914. Subsequently, the Machinery Safety Era took place from 1914 until 1952. During this era, the Machinery Enactment 1913 replaced the various steam boiler enactments of Allied Malay States on $1^{\text {st }}$ January 1914. The development of safety and health at workplace expanded in the following era of the Industrial Safety Era that took place from 1953 until 1969. In 1953, the Machinery Ordinance 1953 was enacted to replace all previous legislations. Subsequently, in 1967, the Parliament had approved the Factory and Machineries Act (FMA 1967). Between the years 1970 until 1994, the era was called the Industrial Safety and Hygiene Era. In this era, few modifications were made. Starting in 1970, the Factory and Machineries Act 1967 and eight of its regulations were enforced replacing the Machinery Ordinance 1953. In 1980, the application of the Factory and Machineries Act 1967 was extended to Sabah and Sarawak. Since the year 1994, it is the Occupational Safety and Health Era where the Parliament passed a new legislation known as the Occupational Safety and Health Act (OSHA) 1994 which was gazetted on February 1994.

It is important to note that since manufacturing is one of the major contributors to the Malaysian economy, the development of manufacturing sector must also be in line with the awareness and compliance of the industry towards safety and health. The policy for manufacturing in Malaysia does not only cover technology, market access, productivity and financial component but must also consider numerous hazards in the work environment. Various occupational and health issues such as exposure to chemical, lack of trained workers and deficiency in enforcement must be appropriately managed.

\subsection{Manufacturing Industries}

To understand safety culture in the manufacturing sectors in Malaysia, it is important to understand what constitutes 'manufacturing sector'. According to the Industrial Co-ordination Act 1975 (ICA), 'manufacturing activity' is defined as the making, altering, blending, ornamenting, finishing or otherwise treating or adapting any article or substances with a view to its use, sale, transport, delivery or disposal; and includes the assembly of parts and hip repairing but shall not include any activity normally associated with retail or wholesale trade. The ICA requires manufacturing companies with shareholders' funds of RM2.5 million and above or engaging 75 or more full-time paid employees to apply for a manufacturing license for approval by the Ministry of International Trade and Industry (MITI). Applications for manufacturing licenses are to be submitted to the Malaysian Industrial Development Authority (MIDA), an agency under MITI.

MIDA is the government's principal agency for the promotion of the manufacturing and services sectors in Malaysia. MIDA assists companies which intend to invest in the manufacturing and services sectors, as well as facilitates the implementation of their projects. The wide range of services provided by MIDA includes providing information on the opportunities for investments, as well as facilitating companies which are looking for joint venture partners. MIDA classified manufacturing sector in Malaysia into twelve industries, which are basic metal products, electrical and electronic, electronics manufacturing services, engineering supporting, food processing, machinery and equipment, medical devices, petrochemical and polymer, pharmaceuticals, rubber products, textiles and apparel and wood-based industries.

Another body which is closely related with manufacturing sectors in Malaysia is Federation of Malaysia Manufacturers (FMM). FMM has been established since 1968 and acts as representative for the manufacturing industries. FMM operates as a business organization which promotes and support manufacturing sector's interests. FMM classifies the organization registered with its body according to International Standard Industrial Classification (ISIC) Codes. Based on this ISIC Codes, products manufactured in manufacturing industries classified into 23 categories. They are food products and beverages, tobacco products, textiles, wearing apparel, tanning and dressing of leather, wood and products of wood and cork, except furniture, paper and paper products, publishing, printing and reproduction of recorded media, coke, refined petroleum products and nuclear fuel, chemicals and chemical products, rubber and plastics products, other non-metallic mineral products, basic metal, 
fabricated metal products except machinery and equipment, machinery and equipment N.E.C., office, accounting and computing machinery, electrical machinery and apparatus N.E.C., radio, television and communication equipment and apparatus, medical, precision and optical instruments, watches and clocks, motor vehicles, trailers and semi-trailers, other transport equipment, manufacture of furniture and recycling.

\section{Occupational Safety and Health Problems in the Malaysian Manufacturing Sector}

There are two main problems relating to occupational safety and health in the Malaysian manufacturing sector discussed below:-

\subsection{High Accident in Manufacturing Industries Which Could Be Due to Lack of Safety Culture}

In the industrialized nations of the world, workplace accident has become a major problem, which is supported by Biggs, Sheahan \& Dingsdag (2005), who concurs that accidents now cause more deaths than all infectious diseases and more than any single illness except those related to heart disease and cancer. An analysis from the Chernobyl 1986 nuclear power plant accident has also suggested that inadequate organizational safety culture was a possible major contributor to the accident. It was not necessarily due to less than optimum engineering design or equipment failure, but people's 'poor' human factor (Taylor, 2010). This suggestion was indeed put up more than 70 years ago by Heinrich (1941), who advocated that $88 \%$ of all accidents were caused by unsafe acts of people, $20 \%$ were by unsafe machines or conditions while another $2 \%$ were by acts of God (force majeure). In Malaysia, although manufacturing sector contributes significantly to the national income, the existence of safety culture in this sector is still questionable.

Table 1. Accidents reported to SOCSO by sectors

\begin{tabular}{|c|c|c|c|c|c|c|c|c|c|}
\hline Industries/Year & 2001 & 2002 & 2003 & 2004 & 2005 & 2006 & 2007 & 2008 & 2009 \\
\hline Manufacturing & 35,642 & 33,523 & 29,780 & 26,690 & 23,350 & 21,609 & 19,607 & 19,041 & 17,206 \\
\hline $\begin{array}{l}\text { Trade/wholesale } \\
\text { and retail }\end{array}$ & 13,774 & 13,685 & 13,395 & 12,948 & 11,930 & 11,430 & 11,658 & 9,741 & 9,197 \\
\hline $\begin{array}{l}\text { Public Service (non } \\
\text { government) }\end{array}$ & 7,487 & 8,140 & 7,743 & 8,325 & 8,502 & 8,502 & 8,309 & 3,912 & 4,128 \\
\hline Other Service & 5,950 & 5,924 & 5,617 & 5,295 & 4,570 & 4,832 & 4,718 & 11,078 & 12,467 \\
\hline Construction & 4,593 & 5,015 & 4,654 & 4,445 & 3,948 & 3,686 & 3,703 & 3,814 & 4,108 \\
\hline Transportation & 4,382 & 4,439 & 4,104 & 4,151 & 3,643 & 3,610 & 3,639 & 3,305 & 3,690 \\
\hline $\begin{array}{l}\text { Agriculture, } \\
\text { forestry and fishing }\end{array}$ & 12,424 & 9,456 & 6,947 & 5,644 & 3,734 & 3,567 & 3,255 & 3,594 & 2,696 \\
\hline $\begin{array}{l}\text { Finance and } \\
\text { insurance }\end{array}$ & 602 & 567 & 572 & 605 & 581 & 538 & 612 & 718 & 780 \\
\hline $\begin{array}{c}\text { Electricity, gas and } \\
\text { water }\end{array}$ & 442 & 516 & 510 & 496 & 465 & 509 & 476 & 524 & 544 \\
\hline $\begin{array}{l}\text { Mining and } \\
\text { quarrying }\end{array}$ & 573 & 545 & 536 & 533 & 459 & 394 & 362 & 368 & 370 \\
\hline TOTAL & 85,869 & 81,810 & 73,858 & 69,132 & 61,182 & 58,321 & 56,339 & 56,095 & 55,186 \\
\hline
\end{tabular}

Source: SOCSO

As shown in Table 1, statistics from the Social Security Organization (SOCSO) show that from the year $2001-$ 2009 , the manufacturing sector recorded the highest number of reported accidents fatalities as compared to other industries in Malaysia. This leads to the question of "whether, in the quest of optimizing productivity, employers do pay enough concern on the safety and health of the employees?" Since manufacturing is one of the major contributors to the Malaysian economy, the development of the manufacturing sector must also be in line with the awareness and compliance of the industry towards safety and health.

From the statistics by DOSH (2010) on fatal occupational accidents classified according to sectors for the year 2007 - 2010 in Malaysia as shown in Figure 1, 2, 3 and 4, the manufacturing sector stands as the second highest 
sector for the year 2007, 2009 and 2010 respectively. The statistics indeed took a deeper plunge in 2008 when occupational accidents in the manufacturing sector scored the highest rate of fatality.

Occupational Accidents By Sector For The Category of Death Until Decem ber 2010 ( Investigated)

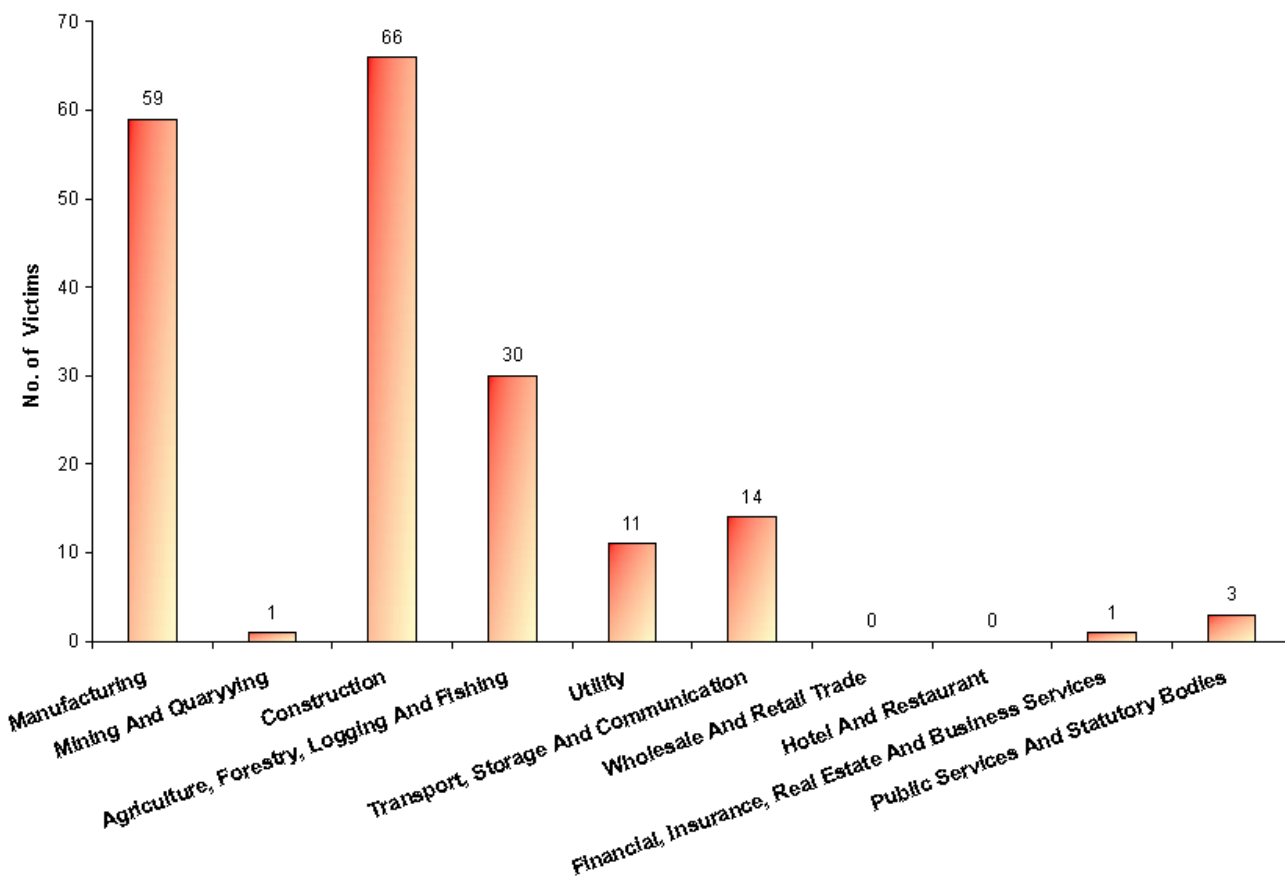

Figure 1. Occupational accidents by sector for the category of death until 2010

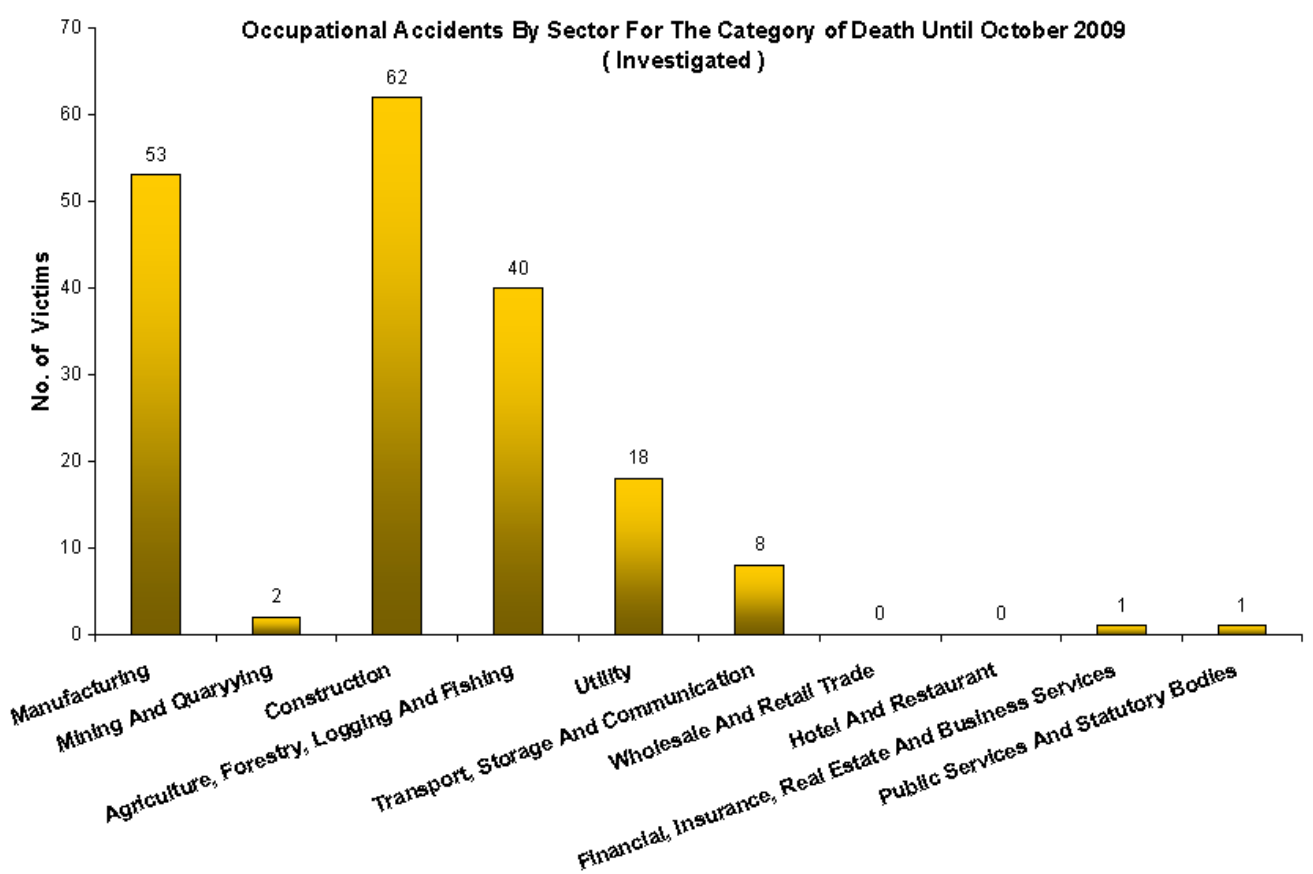

Figure 2. Occupational accidents by sector for the category of death until 2009 


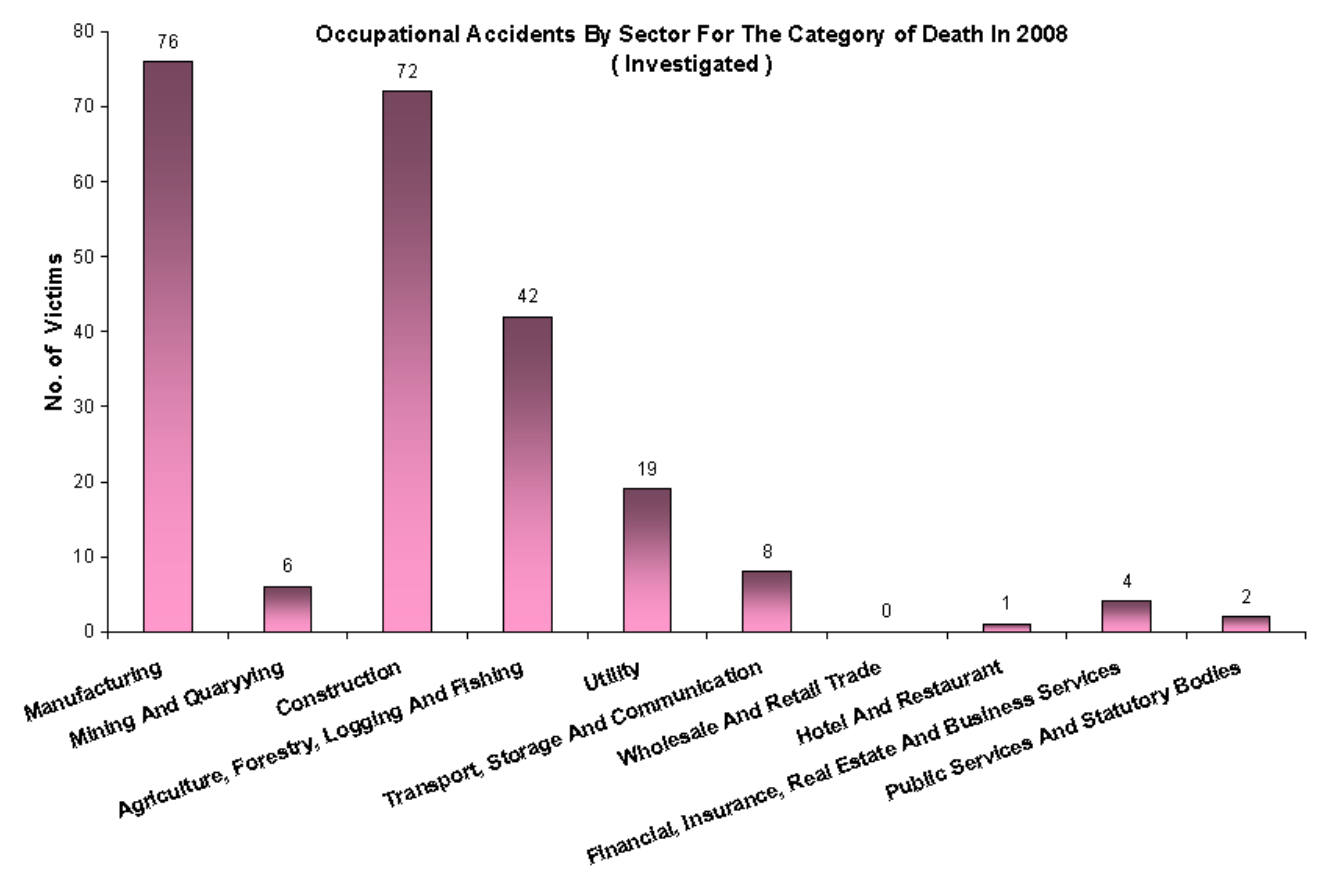

Figure 3. Occupational accidents by sector for the category of death in 2008

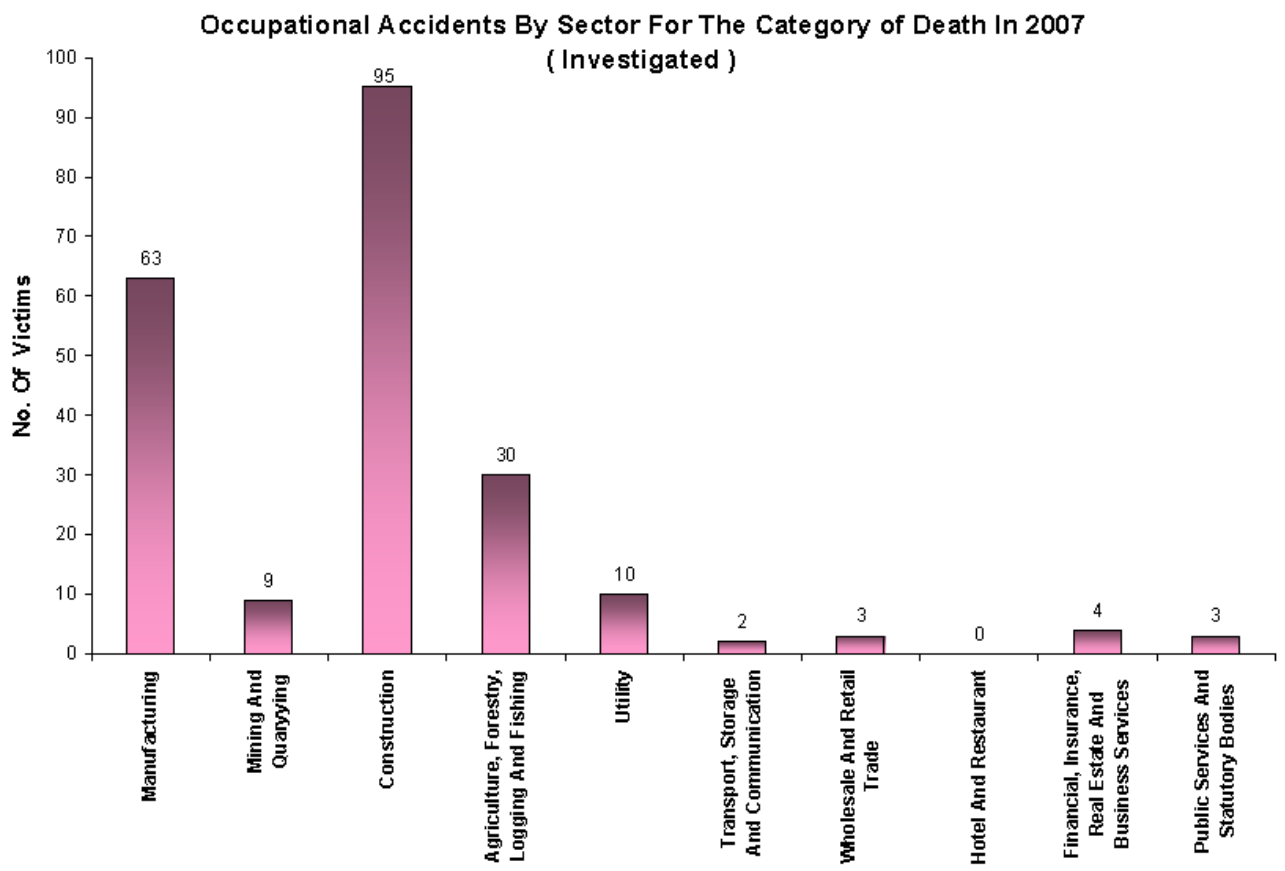

Figure 4. Occupational accidents by sector for the category of death in 2007 


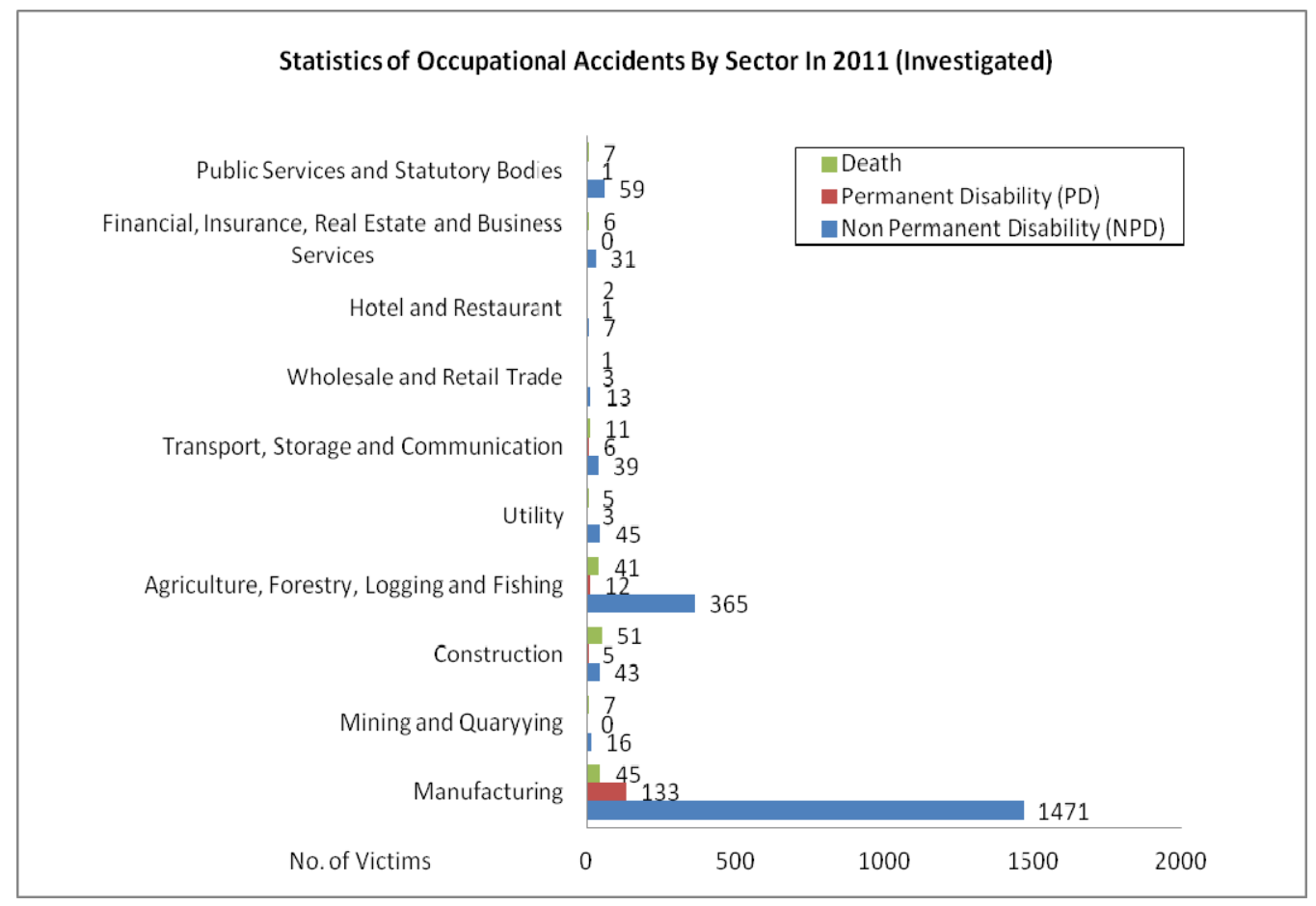

Figure 5. Statistics of occupational accidents by sector in 2011 (investigated)

From the above statistics, it may be deduced that occupational safety is yet to be incorporated as a culture amongst the Malaysian manufacturers. This deduction may be supported with the admission by DOSH itself that occupational safety and health in Malaysia is still at compliance level and has yet to become a culture (DOSH, 2010). The statistic of occupational accidents by sector in 2011 as endorsed by DOSH (Figure 5) also shows that manufacturing sector recorded the highest rate of non-permanent disabilities (NPD) and permanent disabilities (PD) due to occupational accidents with the total of 1471 workers having NPD and 133 workers having PD compared to other sectors (DOSH, 2012).

\subsection{Non-compliance of OSHA's Requirement Have Respectively Led to Lack of Safety Culture in Manufacturing Industries}

\subsubsection{Section 16 - Safety Policy}

Section 16 compels all employers (or self-employed persons) with more than five employees to develop written safety and health policy. It is important to note that non-compliance of this provision may inadvertently contribute to lack of safety culture since according to Health and Safety Executive (1997), safety policy captures the existence of a written declaration reflecting the organization's commitment to safety. This statement is supported by Fernandez-Muniz, Montes-Peon \& Vazquez-Ordas (2007) indicating that safety policy reflects the organization's principles and values towards safety culture.

Mohd Hanip (2007) further strengthens this outlook by stating that the employer's failure to comply with Section 16 of OSHA in the Johor's manufacturing industries has shown significant weaknesses of the employers, who view occupational safety and health as not important. Thus, non-compliance towards Section 16 could be considered a major provenance to lack of safety culture in the manufacturing industries.

The above arguments are further strengthened by Mohd Saidin et. al. (2006), who views that one of the elements in developing safety culture is safety policy. It is believed that combination of rules, believes, attitudes and good practices will create positive safety culture at workplace.

\subsubsection{Section 30 - Safety and Health Committee}

Section 30 of OSHA compels employers of 40 or more employees (or if directed by General Director) to establish safety committee at workplace. For companies with 40 or more employees, the safety committee shall comprise of two representatives each from the employers and employees while companies of 100 employees and more, there should be four representatives each from the employers and employees. 
The functions of the safety committee are mainly to make recommendations to promote and develop measures to ensure the safety and health at the workplace and to monitor the effectiveness of such measures (Xavier, 1996). He further adds that the establishment of such a committee should not be restricted according to the number of workers or to be left to the discretion of the General Director because hazards depend more on the nature of work carried out at the workplace rather than the number of employees. However, Pollock (1995) skeptically views that despite the importance of the employees' involvement in safety programs, many of the safety and health committees were formed with no goals. Finally, they will be split into an empty talk or discussion sessions with no results.

\subsubsection{Section 29 - Safety and Health Officer}

Section 29 compels companies exceeding 100 or 500 employees (depending on the nature of business) to appoint a Safety and Health Officer where non-compliance of this provision may also be relevant to this problem. As suggested previously by Xavier (1996), appointment of a safety and health officer should not be severely restricted according to the number of workers. He further reiterates that the question of danger does not lie in numbers but in the nature of the work carried out at the workplace. Since this is a provision which ensures that compliance with the safety and health provisions of the Act is monitored, he suggests that this compulsion should not be restricted to certain categories of occupation only.

\section{Developing Safety Culture in the Malaysian Manufacturing Sector}

Safety culture can be viewed as a component of the organizational culture that refers to the individuals, jobs, and organizational characteristics that affect employees' health and safety (Fernandez-Muniz et.al., 2007). There has been increasing interest among researchers and practitioners since the past two decades towards the concept of safety culture because of its impact on safety outcomes such as injuries, fatalities, and other incidents (Choudhry, Fang \& Mohamed, 2007) where the aim of safety culture is to avoid taking any unsafe actions (Fernandez-Muniz et.al., 2007).

Heinrich's Domino Theory is the pioneer theory of accident causation in the field of industrial accident safety. According to Heinrich (1941), accidents result from a chain of sequential events, like a line of dominoes falling over. In explaining his theory, Heinrich posited five dominoes in a sequence namely:

1) Social Environment and Ancestry (e.g.: stubbornness, alcoholism, etc.)

2) Fault of the Person (e.g.: carelessness, recklessness, etc.)

3) Unsafe act or unsafe condition

4) Accident

5) Injury

Heinrich also emphasized that the first three (i, ii and iii) combining factors cause accidents and consequently injuries. Apart from the suggestion by Taylor (2010) that the outcome of the investigation of Chernobyl incident which bring into focus the performance of 'the person' managing, designing, constructing or operating hazardous facilities, Heinrich had already suggested that $88 \%$ of all accidents were indeed caused by unsafe acts of people with the rest $20 \%$ were caused by unsafe machines or conditions and another $2 \%$ were caused by acts of God.

According to the Malaysian Department of Occupational Safety and Health (DOSH, 2010), ILO Safety Culture Model has identified different levels of safety culture. These levels of safety culture are influenced by three main independent variables namely:

1) Individuals commitment

2) Managers commitment

3) Policy commitment

Cooper (2000) identifies the characteristics of safety culture model which are; psychological, behavioural and situational factors. Self-regulatory processes have been promoted as a part of this model in reducing risks in organization. This is in fact consistent with Malaysia, where the introduction of self-regulation, through the enactment of the Occupational Safety and Health Act (OSHA) 1994 was to promote safety culture (Faridah, Hasmawati, Razidah \& Muhd. Zaimi, 2010).

In promoting safety culture, DOSH, in its strategies, also looks forward for the outcome of self-regulation for the year 2011-2015. This time frame becomes the indicator for DOSH to meet their target of having OSH culture at workplace in Malaysia for the year 2016-2020 and having preventive culture beyond 2020 (DOSH, 2010). 
It is important to note that, to develop safety culture at workplace, the behavioural aspects of employees should also be measured. Such measure can be done by peer observations to check the readiness of employees, workplace conditions as well as to identify weaknesses at the workplace. One of the appropriate programs to measure employees' behaviour is called Behaviour-based safety (BBS). BBS is characterized as an analytic, objective and data-driven approach focusing on safety-related behaviours performed by first-line personnel (Tharaldsen \& Haukelid, 2009). This program can also be developed for different levels of management (Choudhry et. al., 2007). HSE (2002) supports such program by saying that the output of BBS program will ultimately lead to improving safety culture. Thus, identifying behavioural aspects of employees is a key in developing safety culture in the organizations.

There have been many studies conducted to examine safety-related behaviours as key aspects in promoting safety culture. Zohar (2002), for instance, has emphasized the role of leadership to improve safety while Barling, Loughlin \& Kelloway (2002) examined the role of transformational leadership in promoting safety. Parboteeah \& Kapp (2008) examined positive relationship between safety motivation and safety enhancing behaviors in their study. It is also noteworthy that safety motivation is considered as one of the indicators since the study by Ajzen \& Fishbein (2005) has identified that motivation as an important precursor to actual behaviour. Safety motivations, safety compliance and safety participation were also considered by Parboteeah \& Kapp (2008) simply because employees who are motivated will actively follow safety compliance and participate in safety participation activities.

Apart from that, management commitment is also important in developing positive safety behavioural aspects amongst employees. Employees will be less safety conscious and willing to take more risks to get the work completed if the management does not support the safety process (Borstorff \& Lowe, 2010). Another behavioural aspect that should not be neglected is educational and training programs. According to Root (2005), the organizations must provide training programs in order to increase awareness and provide safe working environment. The extent of employee safety and health training is dependent upon employee occupational factors, company resources available to finance training, importance placed on safety and other organizational factors (Borstorff \& Lowe, 2010).

Therefore, understanding the behavioural aspects amongst employees is important in this study. This is because, positive safety behaviour aspects amongst employees will lead to positive safety culture in the organization. Management who are willing to observe employees' behaviour aspects will promote positive safety behaviour amongst employees which in turn can lead to positive safety culture in organizations.

\section{Conclusion}

Despite more than 18 years have passed since OSHA was first implemented in Malaysia, there has been no revision done on OSHA. Since Malaysia is a fast growing country since the last three decades, there are certain provisions that may no longer be compatible with current situation. For example, in the manufacturing industries, new machineries with new technologies have been introduced which consequentially requires some of OSHA's provision to be revised. As mentioned by Xavier (1996), danger is not based on the number of employees but the nature of the work. The changing work environment most certainly requires change of law.

It is irrefutable that a right combination of rules, believes, attitudes and good practices will create positive safety culture at workplace. This combination seems to be a big challenge to the government and policy makers in order to reduce accident rate in manufacturing industries. Even if the laws are well developed, the question remains whether these laws are properly enforced and complied by the industries? If managers only focus on how to get more profit rather than how to reduce accident rate at the workplace and supervisor's mindset is more on productivity rather than safety, this leads to another question on how positive attitude and perception can be developed among production employees?

As a conclusion, the DOSH who is responsible in the enforcement of OSHA must relook in the relevance of OSHA in this new era of industrialization. Revisions and amendments to the law must be carried out to make it more compatible to all the industries particularly those high levels of accident rates like the manufacturing industries. Commitment from government agencies, employers and employees are also needed to ensure safety issues become a culture in the industries because reducing accident rates, in the long run, would prove to be more cost effective to the employers.

\section{References}

Abdul Rahman, B. (2006). Keynote address "Driving Improvements in Occupational Safety and Health". In K. Soehod, \& L. Laxman (Eds.), Law on Safety and Health in Malaysia. Fakulti Pengurusan dan Pembangunan 
Sumber Manusia, Universiti Teknologi Malaysia.

Ajzen, I., \& Fishbein, M. (2005). The Influence of Attitudes on Behavior. In D. Albarracin, B. T. Johnson, \& M. P. Zanna (Eds.), The Handbook of Attitudes (pp. 173-221). Erlbaum, Mahwah, NJ.

Barling, J., Loughlin, C., \& Kelloway, E. K. (2002). Development and Test of a Model Linking Safety-Specific Transformational Leadership and Occupational Safety. Journal of Applied Psychology, 87(3), 488-496. http://dx.doi.org/10.1037/0021-9010.87.3.488

Biggs, H. C., Sheahan, V. L., \& Dingsdag, D. P. (2005). A Study of Construction Site Safety Culture and Implications for Safe and Responsive Workplaces. The Australian Journal of Rehabilitation Counselling, $11(1), 1-8$.

Borstorff, P. C., \& Lowe, S. K. (2010). The Culture of Safety: How Important To Employee Health? International Journal of Business Research, 10(5), 147-156.

Choudhry, R. M., Fang, D., \& Mohamed, S. (2007). Developing a Model of Construction Safety Culture. $\begin{array}{lll}\text { Journal of Management in 207-212. } & \text { Engineering, }\end{array}$ http://dx.doi.org/10.1061/(ASCE)0742-597X(2007)23:4(207)

Cooper, M. D. (2000). Towards a Model of Safety Culture. Safety Science, 36, 111-136. http://dx.doi.org/10.1016/S0925-7535(00)00035-7

DOSH. (2010, April 16). Occupational Safety and Health Act 1994 (Act 514). Retrieved from http://www.dosh.gov.my

DOSH. (2010, April 16). The Role and Development. Retrieved from http://www.dosh.gov.my

DOSH. (2012, August 15). Statistics of Department. Retrieved from http://www/dosh.gov.my

Faridah, I., Hasmawati, H., Razidah, I., \& Muhd Zaimi, A. M. (2010). A Framework of Safety Culture for the Malaysian Construction Companies: A Methodological Development. Pertanika J. Soc. Sci. \& Hum, 18(1), 45-54.

Fernandez-Muniz, B., Montes-Peon, J. M., \& Vazquez-Ordas, C. J. (2007). Safety culture: Analysis of the Causal Relationships between Its Key Dimensions. Journal of Safety Research, 38, 627-641. http://dx.doi.org/10.1016/j.jsr.2007.09.001

Gadd, S., \& Collins, A. M. (2002). Safety Culture: A Review of the Literature. Report No. HSL/2002/25, Sheffield: Health and Safety Laboratory, Human Factors Group, pp. 8-30.

Guldenmnund, F. W. (2000). The Nature of Safety Culture: A Review of Theory and Research. Safety Science, 34(1-3), 215-257.http://dx.doi.org/10.1016/S0925-7535(00)00014-X

Health and Safety Executive (HSE). (1997). Successful Health and Safety Management, HSG65. London: HSE Books.

Health and Safety Executive (HSE). (2002). Evaluating the Effectiveness of the Health and Safety Executives Health and Safety Climate Survey Tool. Prepared by the Keil Centre. Research Report 042.

Heinrich, H. W. (1941). Industrial Accident Prevention: A Scientific Approach (2nd ed.). McGraw-Hill Book Company Inc.

Industrial Co-ordination Act 1975 (ICA). (2006). Percetakan Nasional Malaysia Bhd.

Mohd Hanip, A. (2007). Tahap Pengamalan Pengurusan Keselamatan Dalam Industri kecil dan Sederhana. Fakulti Kejuruteraan Mekanikal, Universiti Teknologi Malaysia.

Mohd Saidin, M., Abdul Hakim, M., Sulaiman, K., Zakaria, M.Y., Wan Yusoff, W. M., \& Ahmadon, B. (2006). Pembangunan Budaya Keselamatan dalam Industri Pembinaan, proceedings of the International Conference on Construction Industry 2006 (ICCI 2006). June 21-25. Padang, Sumatera Barat.

Ostrom, L., Wilhelmsen, C., \& Kaplan, B. (1993). Assessing Safety Culture. Nuclear Safety, 34(2).

Parboteeah, K. K., \& Kapp, E. (2008). Ethical Climates and Workplace Safety Behaviours: An Empirical Investigation. Journal of Business Ethics, 80(3), 515-529. http://dx.doi.org/10.1007/s10551-007-9452-y

Pollock, J. L. (1995). Cognitive Carpentry: A Blueprint for How to Build a Person. Cambridge, MA: MIT Press.

Rantanen, J., Lehtinen, S., \& Savolainen, K. (2004). The Opportunities and Obstacles to Collaboration between the Developing and Developed Countries in the Field of Occupational Health. Toxicology, 198, 63-74. http://dx.doi.org/10.1016/j.tox.2004.01.038 
Root, D. (2005). Creating a Culture of Safety on Construction Sites. Risk Management, 52(11), 56-62.

Soehod, K., \& Laxman, L. (2007). Law on Safety and Health in Malaysia. Fakulti Pengurusan dan Pembangunan Sumber Manusia, Universiti Teknologi Malaysia.

Taylor, J. B. (2010). Safety Culture: Assessing and Changing the Behaviour of Organisations. Gower Publishing.

Tharaldsen, J., \& Haukelid, K. (2009). Culture and Behavioural Perspectives on Safety - towards a Balanced Approach. Journal of Risk Research, 12(3/4), 375-388. http://dx.doi.org/10.1080/13669870902757252

Xavier, G. (1996). Health and Safety at Work. Current Law Journal, 2.

Zohar, D. (2002). The Effects of Leadership Dimensions, Safety Climate, and Assigned Priorities on Minor Injuries in Work Groups. Journal of Organizational Behavior, 23, 75-92. http://dx.doi.org/10.1002/job.130 